\title{
Preparation and Characterisation of Bio-Oil Produced from Sawdust of Selected Wood Species
}

\author{
Idowu Abimbola Adegoke ${ }^{1, \text { *, }}$, Rotowa Odunayo James ${ }^{2}$ \\ ${ }^{1}$ Department of Forestry and Wildlife Management, Faculty of Agriculture, Federal University Gashua, Gashua, Nigeria \\ ${ }^{2}$ Department of Forestry and Wildlife Management, Faculty of Agriculture, Nasarawa State University, Shabu-Lafia Campus, Nasarawa, \\ Nigeria
}

Email address:

adegokeabimbola4u@yahoo.com (I. A. Adegoke)

*Corresponding author

\section{To cite this article:}

Idowu Abimbola Adegoke, Rotowa Odunayo James. Preparation and Characterisation of Bio-Oil Produced from Sawdust of Selected Wood Species. American Journal of Modern Energy. Vol. 6, No. 1, 2020, pp. 16-25. doi: 10.11648/j.ajme.20200601.13

Received: March 22, 2019; Accepted: April 30, 2019; Published: January 21, 2020

\begin{abstract}
Renewable energy is of growing importance in satisfying environmental concerns over fossil fuel usage. The study was carried out to determine bio-fuel characteristics of pyrolytic oil produce from sawdust of selected wood species (Gmelina arborea, and Nesogordonia papaverifera). Sawdust samples of 200 gramms each were collected from Forestry Research Institute of Nigeria sawmill and oven-dried at $103 \pm 2^{\circ} \mathrm{C}$ for 24 hours to $12 \%$ moisture content. While four replicates of bio-oil were produced at each temperature regime for each of the samples, two different temperature regimes were used $\left(500^{\circ} \mathrm{C}\right.$ and $\left.600^{\circ} \mathrm{C}\right)$. The metallic container (pyrolytic chamber) was filled with 200 grammes of the samples of each species and placed inside the Reactor which was connected to a condenser. Using standard test, physical properties, chemical and thermal characterization of bio oil and proximate analysis of the Bio-Char were assessed. Analysis of Variance (ANOVA) in Randomized Complete Block Design (RCBD) was used to ascertain significance difference in the oil yield produced at different temperature. The result shows that there was general increase in the volume of oil yield as the temperature increases. The volume of the oil ranged between $35.97 \pm 1.82$ to $49.33 \pm 3.21$ and $52.93 \pm 0.51$ to $63.63 \pm 5.83$, the highest and least mean of the $\mathrm{pH}$ of pyrolytic oil yield ranged from $3.52 \pm 0.02$ to $3.54 \pm 0.02$ and $3.64 \pm 0.36$ to $3.73 \pm 0.01$ for $G$. arborea and $N$. papaverifera respectively. There was significant difference in the means of the volume of bio-oil obtained as pyrolysis temperture increases. It further shows that the sawmill wood residues differs significantly at $\mathrm{P}<0.05$ within the two temperature regime. The study established that pyrolysis is an efficient way to produce liquid fuels from biomass. The physical properties of the bio-oil obtained from sawmill wood residues falls within the acceptable range for fuel production. The selected wood species are therefore suitable for production of bio-oil with acceptable physical and chemical properties. Based on the result of the study, it is therefore among others recommended that residence time be taken for each temperature range to convert the feedstock to oil, and quantity of oil yield per specie.
\end{abstract}

Keywords: Temperature, Gmelina Arborea, Pyrolysis, Nesogordonia Papaverifera and Bio-Oil

\section{Introduction}

Biomass is the general terminology to describe all organic materials stemming from green plants that store solar energy in chemical bonds through photosynthesis. Wood and other forms of biomass have served as major fuels for thousands of years sincemankind first began to use fire for heating and cooking. Recently, interest in biomass utilization has increased owing to growing concern over the depletion of fossil fuels andglobal warming caused by greenhouse gas production from fossil fuel combustion. Growing interest in renewable technologies has led to the development of hydroelectric, solar, wave, geothermal, and wind power plants that can potentially displace fossil fuel based energy production [1]. However, existing infrastructures require hydrocarbons for manufacturing goods ranging from plastics and chemicals to fuel oil, lubricating oil, and hydraulic fluids. This has led many to look towards biomass as the only sustainable alternative to fossil fuels capable of yielding 
petroleum like products [2, 3]. As is the case with all potentially disruptive technologies, though, proper environmental mitigation and lifecycle planning must be included when considering the production and use of biofuels
$[4,5]$. Hydrocarbons can be produced from biomass via biological, biochemical, and thermochemical processes as shown in Figure 1 [6].

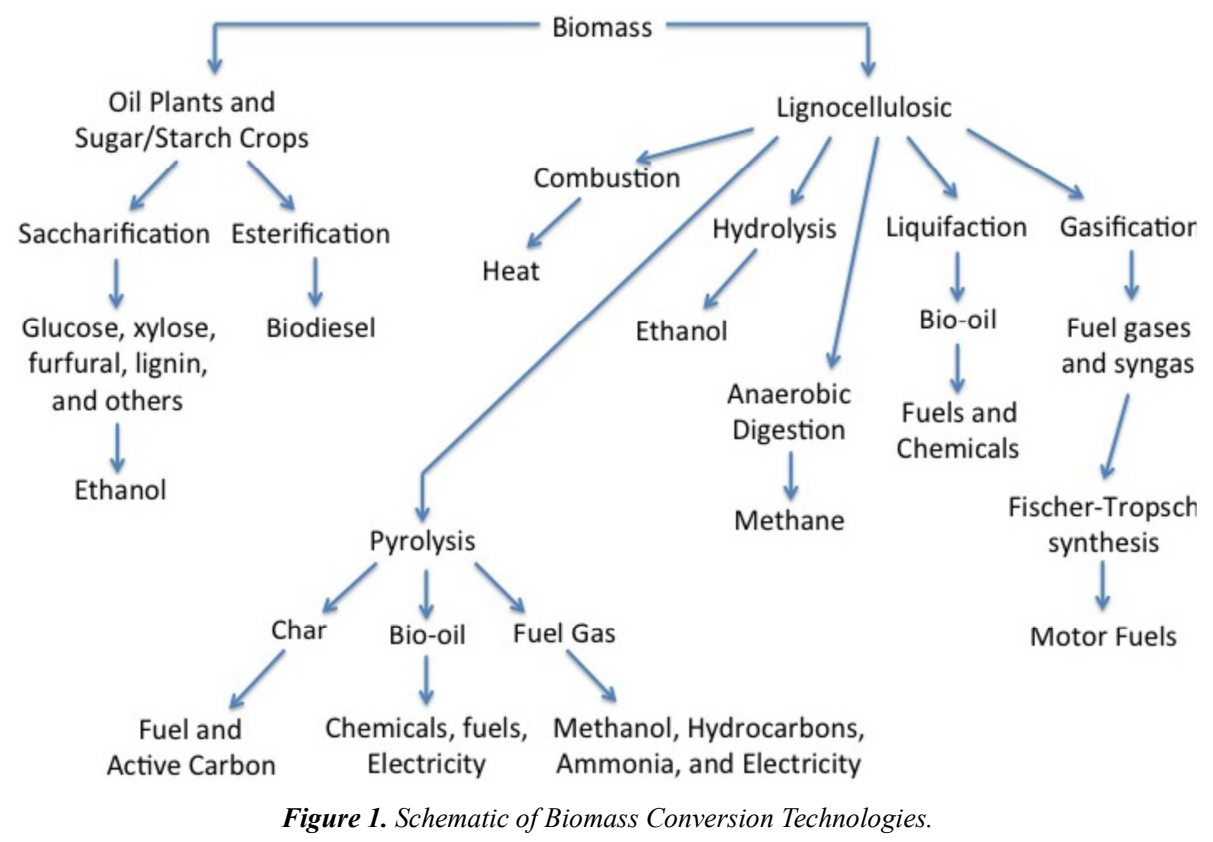

Pyrolysis is the thermal decomposition of fuel into liquids, gases, and char (solid residue) in the absence of oxygen. It is usually understood to be anhydrous (without water). Pyrolytic products can be used as fuels, with or without prior upgrading, or they can be utilized as feedstock for chemical or material industries. Because of the nature of the process, yield of useful products is high compared to the other processes. In general, pyrolytic products are more refined and therefore can be used with greater efficiency. Materials suitable for pyrolysis processing include coal, animal and human waste, food scraps, paper, cardboard, plastics, rubber and biomass [7]. Pyrolysis is believed to be one of the most promising thermochemical technologies with the potential to convert cheap, local, and abundant lignocellulosic biomass such as grasses and trees into a useful form [8, 9], and commercial scale plants. Thermal technologies include direct combustion, gasification, liquefaction, and pyrolysis, all of which have the benefit of using lignocellulosic materials. Only pyrolysis and liquefaction produce a liquid product, and although recent work on liquefaction has shown promising results $[10,11,7]$, it is currently a nascent technology with high capital costs due to the high pressures required. Pyrolysis has the advantage of low capital investment and a liquid final product that can be transported and converted via catalysis to fuels and valuable products such as food flavorings, fertilizers, resins, and other specialty chemicals that are fully compatible with existing petroleum infrastructure. This provides significant economic advantages over ethanol that requires parallel infrastructures. Furthermore, all pyrolysis products can be utilized in the pyrolysis system. The alaming poor energy supply and distribution has necessitated renewed research into alternative source of energy. Although, Nigeria is an oil producing country, but it concentrated on exporting of crude oil and import refined petroleum products since refineries in the country operate below $10 \%$ production capacity. [12]. The high prices of oil which has a disproportionate impact on the country economy requires diversification of the energy sector and improve economic power of individuals through the use of biofuel as an alternative energy source. Also, there are serious environmental pollution problems associated with the use of fossil fuel. There is therefore need to identifying the sustainable energy options for energy production without polluting the environment.

\section{Materials and Methods}

\subsection{Sample Collection and Preparation}

Sawdust samples of Gmelina arborea, and Nesogordonia papaverifera (200 gramms each) were collected from Forestry Research Institute on Nigeria sawmill, the sawdust were oven-dried at $103 \pm 2{ }^{\circ} \mathrm{C}$ for 24 hours to $12 \%$ moisture content. Four replicates of bio-oil were produced at each temperature regime for each of the samples.

\subsection{Bio Oil Production}

The metallic container (pyrolytic chamber) was filled with 200 grammes of the samples of each species and placed inside the Reactor which was connected to a condenser. Two different temperature regimes were used i.e. $500^{\circ} \mathrm{C}$ and $600^{\circ} \mathrm{C}$. The evolving gas was distilled in the condenser to form pyrolytic oil which was collected inside a conical flask. 


\subsection{Esterification of Bio-Oil (Up Grading)}

The process used was transesterification process using acid

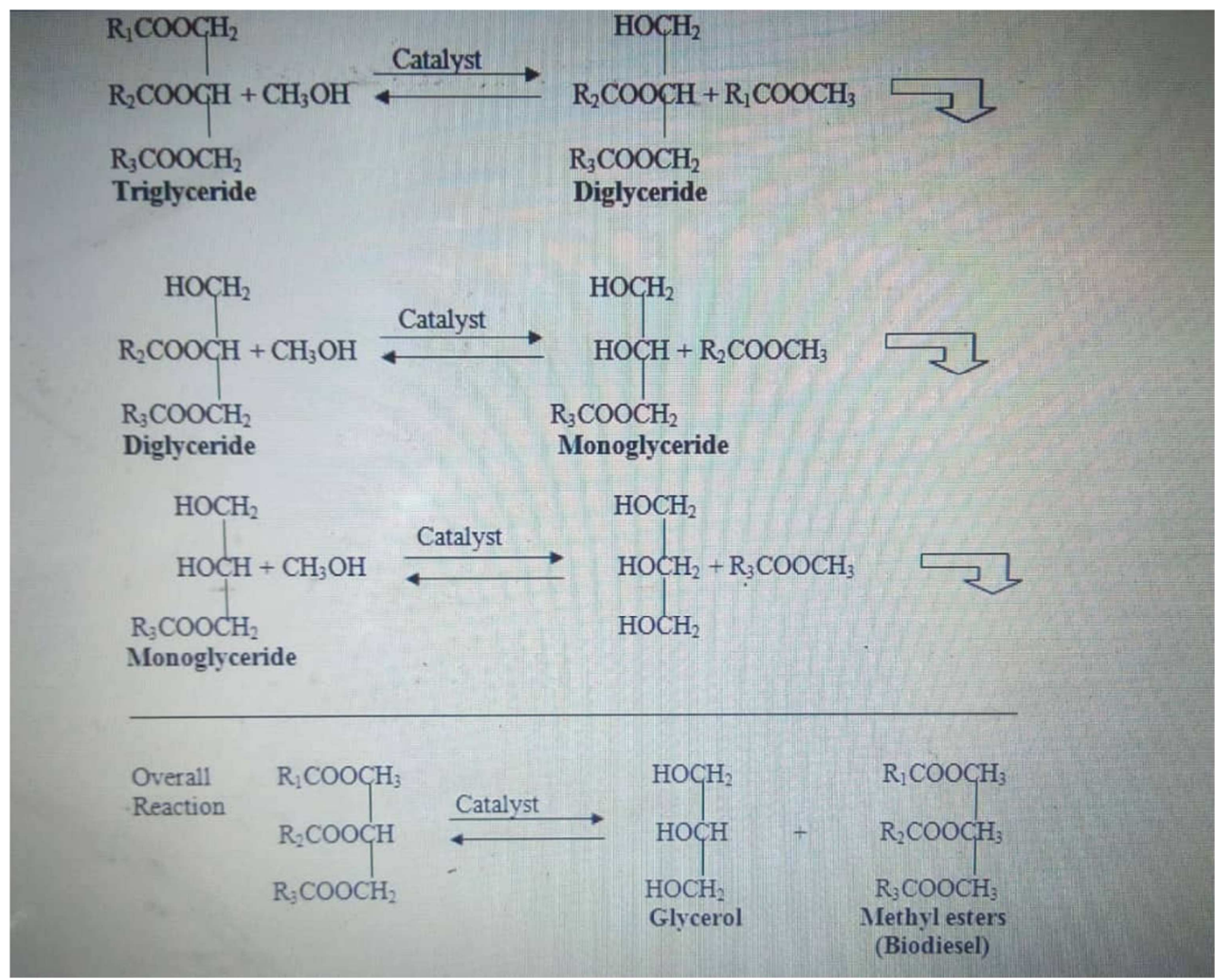

Figure 2. Transesterification reaction of Glycerides with Methanol.

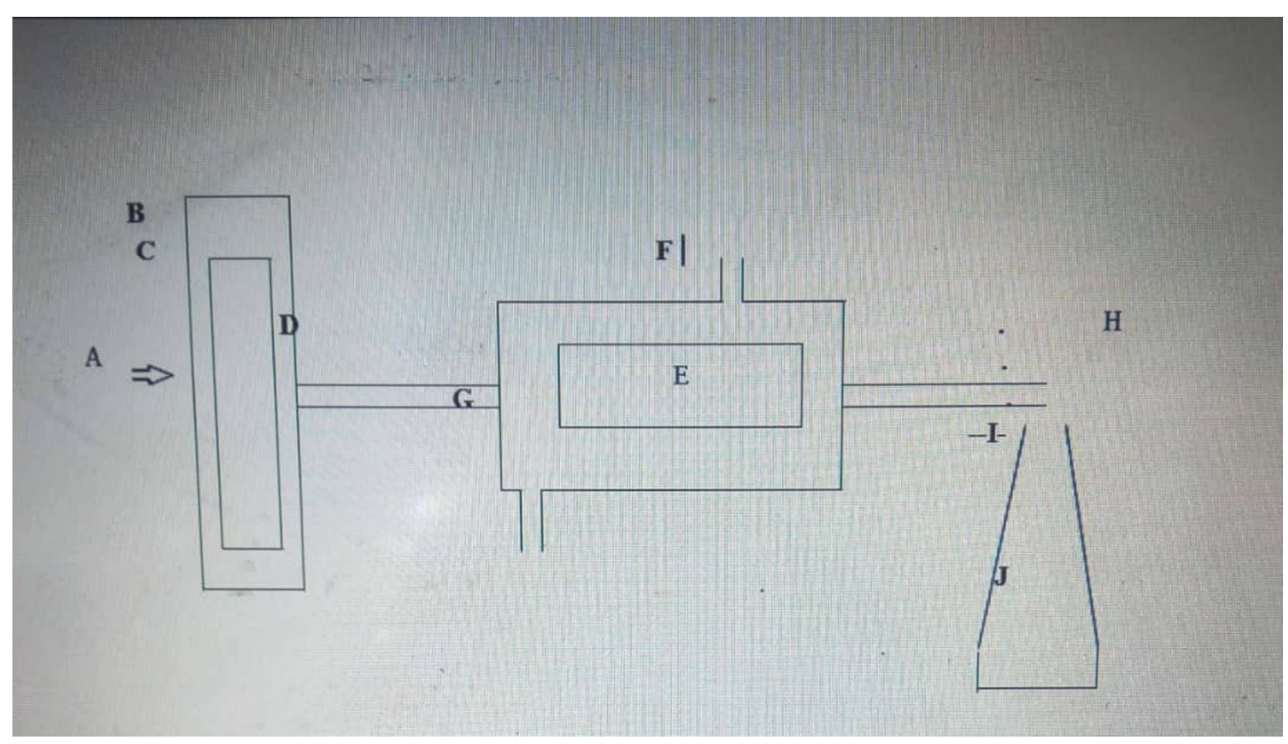

Figure 3. Schematic diagram of Pyrolyser experimental set-up. catalyst.

The reaction sequence is as follow.
$\mathrm{R}_{2} \mathrm{COOCH}+\mathrm{CH}_{3} \mathrm{OH}$
Diglyceride
$\mathrm{R}_{3} \mathrm{COOCH}_{2}$
Digly

Overall

Reaction

A: Feedstock (sawdust).

B: Pyrolytic chamber (Reactor).

C: Furnace.

D: Chamber rod (Liquid passage)

E: Condenser.

F: Cold water inlet.

G: Cold water outlet.

$\mathrm{H}$ : Emitted gas.

I: Pyrolytic oil and tar.

$\mathrm{J}$ : Conical flask. 


\subsection{Fuel Characterization Examination}

To characterize the bio oil and char, the following tests were performed using standard test.

\subsubsection{Physical Properties Characterization of Bio Oil i. $p H$ Determination}

The $\mathrm{pH}$ of the condensate was determined with the use of MICROFIED SM-3H pH meter which has an electrode that was calibrated with two buffer solutions.

\section{ii. Density Determination}

The density of a material is defined as mass per unit volume of sample. Electronic weighing balance was used to weigh the samples while measuring cylinder was used to determine the volume.

$$
\text { Density }\left(\mathrm{g} / \mathrm{cm}^{3}\right)=\frac{\text { Mass }}{\text { Volume }}
$$

Where: $\mathrm{M}=$ mass of the bio-oil obtained $(\mathrm{g}), \mathrm{V}=$ volume of bio-oil obtained $\left(\mathrm{cm}^{3}\right)$

\subsubsection{Proximate Analysis of the Bio-Char}

Proximate analysis was carried out to determine the following:

1. Percentage Ash Content.

2. Percentage Volatile Matter.

3. Percentage fixed Carbon.

4. Heating Value.

i. Percentage Ash Content

Two grams of oven dried sample was kept in furnace at temperature of $550^{\circ} \mathrm{C}$ for three hours and was weighed after cooling. The percentage ash content was calculated thus:

$$
\% \text { Ash }=\frac{\mathrm{D} \times 100}{\mathrm{~B}}
$$

Where: $\% \mathrm{~A}=$ Percentage ash, $\mathrm{D}=$ Weight of ash, $\mathrm{B}=$ weight of oven dried sample.

\section{ii. Percentage Fixed Carbon}

The percentage fixed carbon was calculated by subtracting the value of percentage volatile matter and ash content from $100 \%$. It was calculated according to the formula below:

$$
\% \text { fixed carbon }=100-(\% \mathrm{~V}+\% \mathrm{~A})
$$

Where $\% \mathrm{~V}=$ Percentage Volatile Matter.

$\% \mathrm{~A}=$ Percentage Ash Content.

iii. Percentage Volatile Matter

Two grams of pulverized sample was weighed into crucible before transferred into muffle furnace at $550^{\circ} \mathrm{C}$. This was left for 10minutes; the content was later cooled in dessicator and weighed to determine the percentage volatile matter with the formula below:

$$
\text { Volatile Matter }(\%)=\frac{\mathrm{B}-\mathrm{C} \times 100}{\mathrm{~B}}
$$

Where $\mathrm{B}=$ Weight of oven dried samples, $\mathrm{C}=$ Weight of sample after 10 minutes in the furnace at $550^{\circ} \mathrm{C}$.

iv. Heating Value

The heating value or calorific value of a substance, usually a fuel or food is the amount of heat energy released during the combustion of a specified amount of sample. The calorific value is a characteristic for each substance. It is measured in unit of the substance, usually mass, such as $\mathrm{Kcal} / \mathrm{kg}, \mathrm{KJ} / \mathrm{kg}, \mathrm{J} / \mathrm{mol}$, and $\mathrm{Bt} / \mathrm{m}^{3}$. Heating value is usually determined by the use of a bomb calorimeter but due to in availability of bomb calorimeter estimation method was used. Heating value was calculated using the formula below:

$$
\mathrm{HV}=2.326(147.6 \mathrm{C}+144 \mathrm{~V}) \mathrm{Kj} / \mathrm{kg}-
$$

Where $\mathrm{HV}=$ Heating Value, $\mathrm{C}=$ Percentage fixed Carbon $\mathrm{V}=$ Percentage Volatile Matter

\subsubsection{Chemical and Thermal Characterization of Oil}

i. Determination of acid value

This was done according to Pearson (1976). Two grams of oil was weighed into a dried $250 \mathrm{ml}$ Erlenmeyer flask. Thirty millilitres of a solution made of equal volumes of $95 \%$ ethanol and diethyl ether was added to dissolve the oil. The sample solution was then titrated with $0.1 \mathrm{~N}$ methanolic potassium hydroxide solution with the addition of $0.5 \mathrm{ml}$ phenolphthalein solution until a slight pink colour persisted for 15 seconds. Blank titration without oil was also carried out under the same condition.

$$
\text { ACID VALUE }=\frac{\text { Titration }(m l x 5.61)}{\text { Wt of sample used }} \quad \mathrm{mg} \mathrm{KOH} / \mathrm{g} \text { oil (6) }
$$

\section{ii. Pour Point}

The temperature at which the oil pour was determined by putting samples inside test tube, then placed in a freezer and the lowest temperature at which the pouring occur was recorded as the pour point.

iii. Elemental Analysis of Bio-Oil

Ultimate analysis is performed to determine the elemental composition of the materials. It was carried out using a LECO CHNS 932 elemental analyzer which providescarbon, hydrogen, nitrogen, sulphur percentage composition of the selected samples. When the sumation of these compositions is subtracted from 100, it gives oxygen percentage composition.

iv. Compositional Analysis (FT-IR)

Spectroscopic analysis using photo spectrometer was performed using PERKIN ELMER 1600 series model to know the functional group present in the bio-oil.

\subsection{Data Analysis}

Analysis of Variance (ANOVA) in Randomized Complete Block Design (RCBD) was used to ascertain significance difference in the oil yield produced at different temperature. Duncan Multiple Range Test (DMRT) was used for any variables (temperature and wood specie) that are significant at $5 \%$ level of probability as follow-up test. Ten Chemical properties were assessed for each specie. 


\section{Result and Discussion}

\subsection{Results}

\subsubsection{Pysical Properties and Proximate Analysis of Pyrolytic Oil}

The pyrolytic oil yield from the selected wood species (Gmelina arborea and Nesogodonia papaverifera) at two different temperature regimes $\left(500^{\circ} \mathrm{C}\right.$ and $\left.600^{\circ} \mathrm{C}\right)$ was shown in Table 1. The physical properties which includes bio-oil yield $\left(\mathrm{g} / \mathrm{cm}^{3}\right), \mathrm{pH}$, Acidic value, pour point and Density $\left(\mathrm{g} / \mathrm{cm}^{3}\right)$ of the pyrolytic oil were assessed. The table also shows the result of proximate analysis of the species where percentage fixed carbon, percentage ash content, Percentage, volatile matter, heating value and bio char were assessed.

\subsubsection{Pyrolytic Oil Yield}

There was general increase in the volume of oil yield as the temperature increases. The volume of the oil ranged between $35.97 \pm 1.82$ to $49.33 \pm 3.21$ and $52.93 \pm 0.51$ to $63.63 \pm 5.83$ for Gmelina arborea and Nesogodonia papaverifera respectively (Table 1). There was significant difference in the means of the volume of bio-oil obtained as pyrolysis temperture increases. This further shows that the sawmill wood residues differs significantly at $\mathrm{P}<0.05$ within the two temperature regime (Table 2).

\subsection{3. pH Value of Bio-Oil Yield}

The highest and least mean of the $\mathrm{pH}$ of pyrolytic oil yield which ranged from $3.52 \pm 0.02$ to $3.54 \pm 0.02$ and $3.64 \pm$ 0.36 to $3.73 \pm 0.01$ for Gmelina arborea and Nesogodonia papaverifera respectively were presentedin Table 1 . There is significant difference in the $\mathrm{pH}$ ofbio-oil liquid produced at $500^{\circ} \mathrm{C}$ and $600^{\circ} \mathrm{C}$ for the selected sawmill wood residues at $\mathrm{P}$ $<0.05$ level of significance (Table 2).

Table 1. Physical properties and Proximate analysisof pyrolytic oil produced from the selected wood species (mean \pm standard deviation).

\begin{tabular}{llll}
\hline Physical properties & Temp $\left({ }^{\circ} \mathbf{C}\right)$ & Gmelina arborea & Nesogodonia papaverifera \\
\hline \multirow{2}{*}{ Bio-oil yield $\left(\mathrm{cm}^{3}\right)$} & 500 & $35.97 \pm 1.82^{\mathrm{e}}$ & $52.93 \pm 0.51^{\mathrm{c}}$ \\
& 600 & $49.33 \pm 3.21^{\mathrm{c}}$ & $63.63 \pm 5.83^{\mathrm{b}}$ \\
$\mathrm{pH}$ & 500 & $3.52 \pm 0.02^{\mathrm{a}}$ & $3.64 \pm 0.36^{\mathrm{a}}$ \\
& 600 & $3.54 \pm 0.02^{\mathrm{a}}$ & $3.73 \pm 0.01^{\mathrm{a}}$ \\
Acidic value & 500 & $3.91 \pm 0.27^{\mathrm{b}}$ & $2.54 \pm 0.14^{\mathrm{c}}$ \\
& 600 & $5.49 \pm 4.82^{\mathrm{a}}$ & $-0.85 \pm 0.47^{\mathrm{d}}$ \\
Pour point & 500 & $-0.78 \pm 0.03^{\mathrm{a}}$ & $-0.12 \pm 0.29^{\mathrm{a}}$ \\
& 600 & $-0.80 \pm 0.00^{\mathrm{a}}$ & $0.98 \pm 0.01^{\mathrm{a}}$ \\
Density of bio-oil $\left(\mathrm{g} / \mathrm{cm}^{3}\right)$ & 500 & $0.91 \pm 0.02^{\mathrm{a}}$ & $1.04 \pm 0.11^{\mathrm{a}}$ \\
Proximate analysis & 600 & $0.93 \pm 0.03^{\mathrm{a}}$ & $28.33 \pm 2.89^{\mathrm{b}}$ \\
\% Fixed carbon & & & $56.67 \pm 15.28^{\mathrm{a}}$ \\
& 500 & $25.00 \pm 8.66^{\mathrm{b}}$ & $40.00 \pm 5.00^{\mathrm{a}}$ \\
\% Ash content & 600 & $61.67 \pm 2.89^{\mathrm{a}}$ & $26.67 \pm 7.64^{\mathrm{c}}$ \\
& 500 & $40.00 \pm 5.00^{\mathrm{a}}$ & $31.67 \pm 2.87^{\mathrm{b}}$ \\
\% Volatile matter & 600 & $25.00 \pm 5.00^{\mathrm{c}}$ & $16.67 \pm 7.64^{\mathrm{d}}$ \\
& 500 & $35.00 \pm 5.00^{\mathrm{b}}$ & $20333.89 \pm 1695.70^{\mathrm{b}}$ \\
Heating value & 600 & $13.33 \pm 5.77^{\mathrm{c}}$ & $25037.06 \pm 2686.09^{\mathrm{a}}$ \\
Bio char & 500 & $20305.98 \pm 1737.90^{\mathrm{b}}$ & $97.17 \pm 0.15^{\mathrm{a}}$ \\
& 600 & $25637.17 \pm 1674.89^{\mathrm{a}}$ & $67.60 \pm 3.12^{\mathrm{b}}$ \\
\hline
\end{tabular}

Mean with the same superscript alphabet in a column are not significantly different at $5 \%$ level of probability.

\subsubsection{Acidic Value of Bio-Oil Yield}

The highest and lowest mean value for acidic value of liquid produced from Gmelina arborea and Nesogodonia papaverifera ranged from $3.91 \pm 0.27$ to $5.49 \pm 4.82$ and $1.37 \pm 0.47$ to $2.54 \pm 0.14$ respectively (Table 1 ). The analysis of variance showed that two was significant difference in the acidic value of the pyrolytic liquid at temperature of $500^{\circ} \mathrm{C}$ and $600^{\circ} \mathrm{C}$ (Table 2).

\subsubsection{Pour Point of Bio-Oil Yield}

The mean result of pour point revealed the highest and lowest mean values for the pour point of liquid produced which ranged from $-0.78 \pm 0.03$ to $-0.80 \pm 0.00$ and $-0.85 \pm$ 0.05 to $-0.12 \pm 0.29$ were recorded inGmelina arborea and Nesogodonia papaverifera respectively (Table 1). The result also revealed that there is significant difference in the pour point of bio-oil yield at the two temperature regimes adopted for pyrolysis (Table 2).

\subsubsection{Density of Bio Oil Yield}

The result of density of bio oil yield shows that Gmelina arborea had higher mean density yield of $0.91 \pm 0.02$ to 0.93 $\pm 0.03\left(\mathrm{~g} / \mathrm{cm}^{3}\right)$ and Nesogodonia papaveriferahad a lower yield of $0.98 \pm 0.01$ to $1.04 \pm 0.11\left(\mathrm{~g} / \mathrm{cm}^{3}\right)$ as shown in table 1. The result also revealed that there was significant difference in the density of bio-oil yield at the two temperature regimes adopted for pyrolysis (Table 2).

\subsection{Proximate Analysis of Bio-char Produced from Selected Sawmill Wood Residues}

\subsubsection{Percentage Fixed Carbon}

The result of mean percentage fixed carbon is presented in Table 1. The result from analysis of variance shows that there is no significant difference between the selected sawmill wood residues used at different temperature range (Table 2). The percentage fixed carbon values ranged from $25.00 \pm$ 
8.66 to $61.67 \pm 2.89$ and $28.33 \pm 2.89$ to $56.67 \pm 15.28$ for Gmelina arborea and Nesogodonia papaveriferarespectively.

Table 2. ANOVA of Physical propertiesand Proximate analysisof pyrolytic oil produced from the selected wood species.

\begin{tabular}{|c|c|c|c|c|c|}
\hline SV & df & SS & MS & F-cal & Remark \\
\hline \multicolumn{6}{|c|}{ Physical properties } \\
\hline \multicolumn{6}{|c|}{ Bio-oil yield } \\
\hline Treatment & 2 & 821.56 & 410.78 & 39.54 & * \\
\hline Temperature & 1 & 1705.28 & 1705.28 & 164.14 & * \\
\hline Trt*Temp & 2 & 502.62 & 251.31 & 24.19 & * \\
\hline Error & 12 & 124.67 & 10.39 & & \\
\hline $\mathrm{pH}$ & 17 & 3157.13 & & & \\
\hline Treatment & 2 & 0.086 & 0.043 & 61.43 & * \\
\hline Error & 15 & 0.005 & 0.0007 & & \\
\hline Total & 17 & 0.091 & & & \\
\hline \multicolumn{6}{|l|}{ Acidic value } \\
\hline Treatment & 2 & 68.183 & 34.091 & 4.005 & * \\
\hline Error & 15 & 127.677 & 8.512 & & \\
\hline Total & 17 & 195.86 & & & \\
\hline \multicolumn{6}{|l|}{ Pour point } \\
\hline Treatment & 2 & 0.506 & 0.253 & 281.11 & * \\
\hline Error & 15 & 0.013 & 0.0009 & & \\
\hline Total & 17 & 0.519 & & & \\
\hline \multicolumn{6}{|l|}{ Density } \\
\hline Treatment & 2 & 0.024 & 0.012 & 4.00 & * \\
\hline Error & 15 & 0.043 & 0.003 & & \\
\hline Total & 17 & 0.067 & & & \\
\hline \multicolumn{6}{|c|}{ Proximate Analysis } \\
\hline Treatment & 2 & 19.444 & 9.722 & 0.175 & Ns \\
\hline Error & 15 & 833.333 & 55.556 & & \\
\hline Total & 17 & 852.777 & & & \\
\hline \multicolumn{6}{|c|}{$\%$ Ash content } \\
\hline Treatment & 2 & 158.333 & 79.167 & 33.934 & $*$ \\
\hline Error & 15 & 350.000 & 2.333 & & \\
\hline Total & 17 & 508.333 & & & \\
\hline \multicolumn{6}{|c|}{$\%$ volatile matter } \\
\hline Treatment & 2 & 277.778 & 138.889 & 5.952 & \\
\hline Error & 15 & 350.000 & 23.333 & & \\
\hline Total & 17 & 627.778 & & & \\
\hline \multicolumn{6}{|l|}{ Heating value } \\
\hline Treatment & 2 & 17483899.60 & 8741949.79 & 3.15 & Ns \\
\hline Error & 15 & 41661313.30 & 2777420.89 & & \\
\hline Total & 17 & 59145212.90 & & & \\
\hline \multicolumn{6}{|l|}{ Biochar } \\
\hline Treatment & 2 & 705.95 & 352.97 & 2.04 & Ns \\
\hline Error & 15 & 2594.86 & 172.99 & & \\
\hline Total & 17 & 3300.81 & & & \\
\hline
\end{tabular}

* Significant at $5 \%$ level of probability, Ns = Not significant at $5 \%$ level of probability.

\subsubsection{Percentage Ash Content}

The result of percentage ash content for both temperature regimes shows that Nesogodonia papaverifera had the highest mean percentage ash content $(40.00 \pm 5.00$ to $26.67 \pm 7.64)$ while Gmelina arborea had the less mean percentage ash content which ranged from $40.00 \pm 5.00$ to $26.67 \pm 7.64$ (Table 1). The result from analysis of variance shows that there was significant difference between the selected feedstocks at different temperature (Table 2).

\subsubsection{Percentage Volatile Matter}

The result of mean value for percentage volatile matter shows that at $500^{\circ} \mathrm{C}$ Gmelina arborea had 35.00土5.00 and Nesogodonia papaverifera had $31.67 \pm 2.87$ meanwhile
Nesogodonia papaverifera recorded higher mean value of $26.67 \pm 7.64$ and Gmelina arboreahad $13.33 \pm 5.77$ at $600^{\circ} \mathrm{C}$ (Table 1) The result from Table 2 indicated that there was significant difference in the percentage volatile matter between the different sawmill wood residues at different temperature.

\subsubsection{Heating Value of the Bio-Char}

The result also revealed that the higher mean for the heating value of the bio char which ranged from $20305.98 \pm 1737.90$ to $25637.17 \pm 1674.89 \quad(\mathrm{Kj} / \mathrm{kg}) \quad$ was recorded in $G$. arboreaand20333.89 \pm 1695.70 to $25037.06 \pm 2686.09(\mathrm{Kj} / \mathrm{kg})$ which is less was recorded in $N$. papaverifera. (Table 1). The result of analysis of variance 
indicated that there was no significant difference in the heating values of the bio char (Table 2).

\subsubsection{Bio Char Yield Component}

The result of the proximate analysis presented in table 1 also reveals that Gmelina arboreahad the lesser mean of bio char recovery after pyrolysis process and it ranged from $74.70 \pm 2.46$ to $60.30 \pm 0.89$ while $97.17 \pm 0.15$ to $67.60 \pm 3.12$ was recorded in Nesogodonia papaverifera. The result of analysis of variance indicated that there was no significant difference between the left over char as the pyrolytic temperature increases from $500^{\circ} \mathrm{C}$ to $600^{\circ} \mathrm{C}$ between the selected wood species.

\subsubsection{Elemental Analysis of the Bio-oil}

The results of the elemental composition of the pyrolytic oil is presented in Table 3. This revealed the carbon, hydrogen, nitrogen, surphur and oxygen content of the selected sawmill wood residues.

Table 3. Elemental components of pyrolytic oil.

\begin{tabular}{lll}
\hline Parameter (\%) & Gmelina arborea $\mathbf{5 0 0}^{\circ} \mathbf{C}-\mathbf{6 0 0}^{\circ} \mathbf{C}$ & Nesogodonia papaverifera $^{500}{ }^{\circ} \mathbf{C ~}-\mathbf{6 0 0}^{\circ} \mathbf{C}$ \\
\hline Carbon & $51.2-50.8$ & $49.9-50.02$ \\
Hydrogen & $7.08-8.27$ & $6.85-6.76$ \\
Nitrogen & $0.2-0.1$ & $<0.1-<0.1$ \\
Sulphur & $0.6-0.04$ & - \\
Oxygen & $41.46-40.43$ & 43.1543 .22 \\
\hline
\end{tabular}

\subsubsection{Compositional Analysis of the Bio-Oil}

The result of FT-IR spectrum of the liquid obtained from pyrolysis of G. arborea and $N$. papaverifera wood residues from sawmill at different temperature range are shown in 4 and 5 indicated the functional groups of the two selected sawmill wood residues with their corresponding frequencies $\left(\mathrm{cm}^{-1}\right)$ that were identified from FT-IR spectrum.

Table 4. Functional groups present in wood residue of $G$. arborea and N. papaverifera as determined by FT-IR analysis.

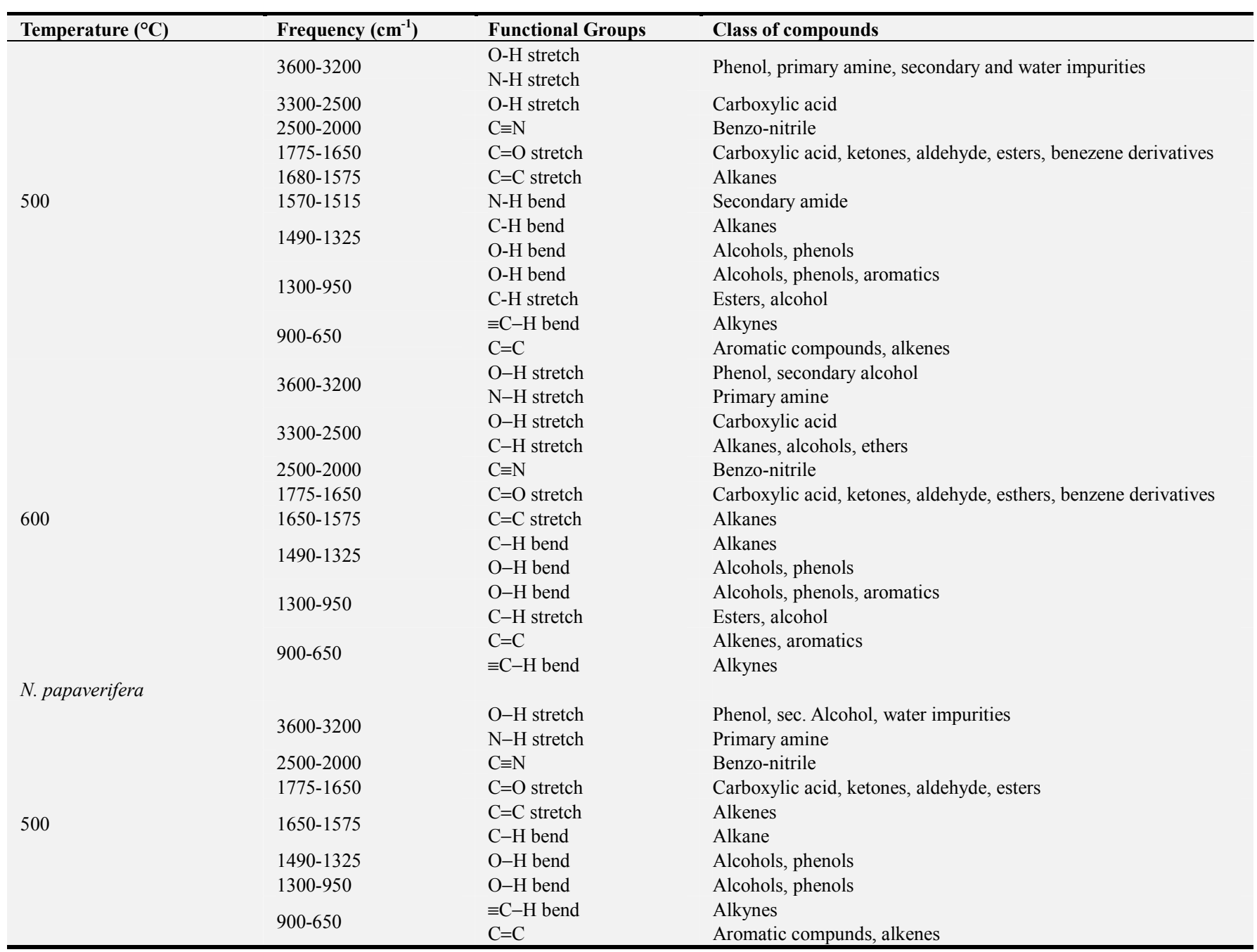




\begin{tabular}{llll}
\hline Temperature $\left({ }^{\circ} \mathbf{C}\right)$ & Frequency $\left(\mathbf{c m}^{-1}\right)$ & Functional Groups & Class of compounds \\
\hline & $3600-3200$ & O-H stretch & Phenols, sec. Alcohol \\
& N-H stretch & Primary amine \\
& $2500-2000$ & Water impurities & Benzo-nitrile \\
600 & $1650-1575$ & $\mathrm{C}=\mathrm{C}$ stretch & Alkenes \\
& $1490-1325$ & $\mathrm{O}-\mathrm{H}$ bend & Alcohols, phenols \\
& C-H bend & Alkanes \\
& $1300-950$ & O-H bend & Alcohols, phenols \\
& C-O stretch & Alcohols \\
& $900-650$ & E-H bend & Alkynes, and aromatic compounds \\
\hline
\end{tabular}

\section{Discussions}

\subsection{Physical Properties of Pyrolytic Oil}

The study revealed that the bio-oil yield was higher at $600^{\circ} \mathrm{C}$ for Nesogodonia papaverifera pyrolysis. At this condition the mean yield of Nesogodonia papaveriferawas $63.63 \mathrm{~g} / \mathrm{cm}^{3}$ compare to $49.33 \mathrm{~g} / \mathrm{cm}^{3}$ yield recorded in Gmelina arborea. There was general increase in the volume of oil yield as the temperature increases. According to [13] the bio-oil derived were not standardized products and can exhibit a wide range of properties and compostion according to the feedstock and pyrolysis technique employed. Considerable experimental evidence suggested that there is increase in yield between liquid and gas and reduction in carbon solids (char) during wood pyrolysis which depends on the heating conditions $[14,15]$. Reported that the cell structure may affect the pyrolysis behaviour of biomass, The liquid yield were high showing the potential of reconversion liquid hydrocabon from the fast pyrolysis of biomass. The liquid appeared brownish dark with a strong acidic smell. Heavy condensate or tar was also formed and adhered to the inner wall of condenser, liquid collectors and connecting pipes. At the initial stage, biomass is decomposed and depolymerized to small compounds by dehydration, dehydrogenation, deoxygenation and decarboxylation and these compounds may rearrange through condensation, cyclization and polymerization to form new compounds.

The characteristics of the oils derived from these three species were very similar to the characteristics of other biomass pyrolytic oils. The most prominent characteristic is the nature of the oil due to high oxygen content as agreed with [16]. A low pH range value of 3.52- 3.73 is a common feature in the sampled species derived liquid and they are thereforevery corrosive. The result of the density presented in table 2 revealed that there is significant difference in the values obtained for $G$. arborea and $N$. papaverifera with $N$. papaverifera having the highest density value of $1.04 \mathrm{~g} / \mathrm{cm}^{3}$ which was high when compared with report of [13] with approximated value of $1.2 \mathrm{~g} / \mathrm{cm}^{3}$. Upon pyrolysis in the temperature range of $500^{\circ} \mathrm{C}-600^{\circ} \mathrm{C}$, the bio-oil yieldof wood samples was higher. Its maximum value was reached at a higher temperature. Upon pyrolysis at $600^{\circ} \mathrm{C}$, the formation of new, thermally more stable bonds occurs. This result agrees with [17], whoseresults also reported higher yield of the char residue and increase in the amount of noncondensing gases upon pyrolysis of the samples. The result of the pour point revealed that $G$. arborea had the highest pour point value of $0.85 \pm 0.05$ at temperature of $600^{\circ} \mathrm{C}$ which will not cause any trouble in most of the tropical regions but in colder regions with sub zero climate it may have freezing problems.

\subsection{Proximate Analysis of Bio-Char Produced from Selected Sawmill Wood Residues}

Proximate analysis is the quickest and simplest way of investigating the fuel quality of solid materials. After pyrolysis the volatile matter content of the selected sawmill wood species reduces between the different samples at different temperature with $G$. arborea having the highest volatile matter content of $35 \%$, which indicates higher biomass to liquid fuels from this species. The result of the percentage ash content presented in table 1 indicated that $N$. papaverifera has the highest ash content (26.67 \pm 7.64$)$ when compared with $G$. arborea $(25.00 \pm 5.00)$ and this may be due to its chemical composition and presence of high extraneous materials percentage ash content, fixed carbon and volatile matter were the required prerequisite for the determination of heating value of the samples. It was observed that there is no significant difference in the percentage fixed carbon between the species and differed significantly for percentage ash content and volatile matter between the species used.

Ash is an impurity that will not burn which reduces handling and burning capacity, it increases handling cost and affects combustion efficency causes clinkering and slagging. The heating value range for the bio-char produced from Gmelina arborea and Nesogodonia papaverifera were obtained as 20305.98 - 25637.17 and 20333.89 - 25037.06 $(\mathrm{Kj} / \mathrm{kg})$ respectively. It is further shown that significant variations are not found among selected sawmill residues. This denotes high heating values as good combustion characteristics for energy generation and to acquire alternative source of bio- briquette for domestic and industrial application [18] Hence, any of these species can be use for industrial combustion needs.

\subsection{Compositional Analysis of the Bio-Oil}

The elemental analysis of the oil is an important criterion for the design of a combustion plant utilizing the oil. The ultimate analysis showed the variations in the elemental 
composition of the selected sawmill wood residues (Table 3). The analysis showed significant variation in carbon and oxygen content whereas there were slight variations in hydrogen, nitrogen and sulphur content. Some of the oxygen in the original feedstock is thought to have turned into $\mathrm{H}_{2} \mathrm{O}$, $\mathrm{CO}$ and $\mathrm{CO}_{2}$. The high oxygen content results in a low energy density of the bio oils. It was observed that changing the temperature causes a slight change in the elemental content of the bio-oil samples. However, no particular trends in the elemental composition were found within the range of reaction temperatures used.

\subsection{Chemical Properties of Pyrolytic Liquid (FT-IR Analysis)}

The FT-IR analysis suggested that the functional groups like alcohols, ketones, carboxylic acids, esters, alkanes, alkenes, alkynes, amide, nitriles, nitro compounds, ethers, aromatic rings were present in the bio-oil from $G$. arborea and $N$. papaverifera. The FT-IR spectra of bio-oil samples obtained from different temperatures exhibited the same peaks but these spectra differed in the relative intensity of some bands. It has to be confirmed with gas chromatography results. The functional groups of the two and various class of compounds that were identified from the FT-IR spectrum are presented in Table 4. The FT-IR spectra were recorded in the transmission mode between 3600 and $600 \mathrm{~cm}^{-1}$ for all samples. All the residues have similar aromatic and aliphatic functional groups but with different vibrating frequencies $\left(\mathrm{cm}^{-1}\right)$.

At $500^{\circ} \mathrm{C}$, the $\mathrm{O}-\mathrm{H}$ stretching vibrating frequency between 3600 and 3200 indicated the presence of phenols and alcohols (-OH in alcohols and phenols). The group and class $-\mathrm{NH}_{2}$ in aromatic amines, primary amines and amides indicate the NH stretching vibrations. The absorbance between 2500 and 2000 represent the presence of benzonitrile with $\mathrm{C} \equiv \mathrm{H}$. The $\mathrm{C}=\mathrm{O}$ deformation vibration between 1775 and $1650 \mathrm{~cm}^{-1}$ indicates the presence of carboxylic acid, ketones, aldehyde, esters and benzene derivatives. The absorption between 1680 and $1575 \mathrm{~cm}^{-1}$ indicated the presence of alkanes. The absorbance peaks between 1575 and 650 represent $\mathrm{N}-\mathrm{H}$ bend, $\mathrm{C}-\mathrm{H}$ bend, $\equiv \mathrm{C}-\mathrm{H}$ bend and $\mathrm{C}=\mathrm{C}$ which further indicated the presence of alkanes, acohols, aromatic compounds and alkynes. The rise in these bands suggests an increase in aromatic structures, nitrogeous compounds and alkanes. The weaker bands suggest a decrease in carbonly groups $(\mathrm{COOH}$, Ketones and aldehydes) as well as aliphatic groups.

[19] Recognized the formation of aromatic compounds, when cellulose was thermo-chemically converted in an alkali solution. They suggested that these aromtic were formed by condensation or cycliation of unstable intermediate fragments, which were generated by degradation of the cellulose. These changes observed by FT-IR indicate that bio oil possess both the aliphatic structures and aromatic components. The changes of intensity of the bands indicated the decrease in aliphatic structure and increase in aromatic components with increasing reaction temperature. At $600^{\circ} \mathrm{C}$ similar functional groups were observed in the FT-IR spectrum in all the selected wood species without any effect of temperature regimes used during pyrolysis. [20, 21] reported that high oxygenated compounds present in biomass pyrolysis oil is responsible for differences in the properties and behaviour of bio-oil. Hence, it is important to deoxygenate the liquid by some upgrading technology.

\section{Conclusion and Recommendations}

\subsection{Conclusion}

Pyrolysis is an efficient way to produce liquid fuels from biomass. The quality of bio-oil has to be improved before it can be used as a traffic fuel or combusted in boilers. During pyrolysis process the solid content in the bio-oil can be reduced by efficient char removal. The bio-oil obtained showed comparable fuel properties and can be treated as moderate grade commercial fuels. In order to utilize it as commercial transportation fuel certain enhancement in properties like density and corrosiveness have to be normalize. The bio-oil obtained contains chemical compounds of varying carbon chain length from $\mathrm{C}_{4}-\mathrm{C}_{27}$ and functional groups such as alkanes, alkenes, alkynes, alcohols, ketones, aldehyde, aromatic rings, amides and nitrile compounds. Bio-char (charcoal) obtained has good calorific value, thus can be used as alternative fuel (briquette production) but it cannot be used as adsorbent as its surface area was quite low. The physical properties of the bio-oil obtained from sawmill wood residues falls within the acceptable range for fuel production. The selected wood species are therefore suitable for production of bio-oil with acceptable physical and chemical properties. The thermal degradation processes (pyrolysis), may help to reduce environmental pollution, deforestation at the same time providing greater amounts of desirable, renewable fuel and chemical source.

\subsection{Recommendations}

Based on the output of this work, the following recommendations are therefore suggested:

1. Residence time taken for each temperature range to convert the feedstock to oil, and quantity of oil yield per specie.

2. Research should be directed to know the effect of particle (feedstock's) size on the yield of bio-oil.

3. Determination of the chemical components in the pyrolytic oil using Gas Chromatography-Mass Spectroscopy (GC-MS).

4. Upgrading of the bio-oil produced to high grade liquid fuel for further use in internal combustion engines and other applications.

5. More research should be conducted on conversion of indigenous wood residues for the production of pyrolytic oil and the following findings should be considered. 


\section{References}

[1] Demirbas A. (2002). Gaseous products from biomass by pyrolysis and gasification. Effect of catalyst on hydrogen yield. Energy Conv Manage 2002; 43: 897-909.

[2] Huber, G. W. (2008). National Science Foundation Report, Breaking the Chemical and Engineering Barriers to Lignocellulosic Biofuels: Next Generation Hydrocarbon Biocarbon Biorefineries, Chemical, Bioengineering, Environmental, and Transport Systems Division, Washington, DC, 2008, 180 p.

[3] Bridgwater, A. V. (2002). An introduction to fast pyrolysis of biomass for fuels and chemicals In Fast pyrolysis of biomass: A handbook, Bridgwater, A. V., Ed., CPLPress: Newbury, UK

[4] Trimble, J. L.; Vanhook, R. I.; Folger, A. G. 1984: Biomass for energy: The environmental-issues. Biomass 6, 3-13.

[5] E. C. $\quad$ http: //ec.europa.eu/research/energy/nn/nn_rt/nn_rt_bm/article_111 1_en.htm. Elliott, D. C. 1986. Analysis and Comparison of Biomass Pyrolysis/Gasification Condesates Final Report, PNL-5943, Contract DE-AC06-76RLO.

[6] Demirbas A. (2001). Biomass resource facilities and biomass conversion processing for fuels and chemicals. Energy Conv Manage 2001; 42: 1357-78.

[7] Adegoke I. A (2017). Physico-Chemical Characterisation of Bio-Oil Produced from Pyrolysis of Gmelina arborea Roxb. Sawdust. Ph. D. submitted to the Department of Forest Resources Management, University of Ibadan. Ibadan, Nigeria

[8] Mohan, D.; Pittman, C. U., Jr.; Steele, P. H. 2006: Pyrolysis of wood/biomass for bio-oil: A critical review. Energy Fuels $20,848-889$.

[9] Lu G. Q, Toyama T, Kim H. J, Naruse I, Ohtake K. (1997). Fundamental study on combustion characteristics of biobriquette. Kagaku Kogaku Ronbun1997; 23: 404-12.

[10] Soria, A. J.; McDonald, A. G.; Shook, S. R. 2008: Wood solubilization anddepolymerization using supercritical methanol. Part 1: Process optimization and analysis of methanol insoluble components (bio-char). Holzforschung, 62, 402-408.

[11] Soria, A. J.; McDonald, A. G.; He, B. B. 2008: Wood solubilization and depolymerization by supercritical methanol. Part 2: Analysis of methanol soluble compounds. Holzforschung, 62, 409-416.
[12] Fuwape, J. A. 2007: Bioenergy: Conservation and Utilization of wood biofuel in Nigeria. In: Proceeding of Division 5 IUFRO conference, October 29-Nov. $2^{\text {nd }} 2007$. Tapei Taiwan. Pp 81.

[13] Solantausta, Y.; Nylund, N. O.; Westerholm, M.; Koljonen, T.; Oasmaa, A. (1993). "Wood Pyrolysis Oil as a Fuel in a Diesel Power Plant.” Bioresource Technology. Vol. 46, 1993; pp. 177-188.

[14] Park, W. CH., Atreya, A., Baum, H. R. (2010). Experimental and theoretical investigation of heat and mass transfer processes during wood pyrolysis, Comb. Flame 157 (2010) 481-494.

[15] Keown, D. M., G. Favas, J. I. Hayashi and C. Z. Li (2005). Volatilisation of alkali and alkaline earth metallic species during the pyrolysis of biomass: differences between sugar cane bagasse and cane trash. Bioresource Technology. 95: 1570-1577.

[16] Bio Therm (1999). BiothermTM A system for continuous quality, fast pyrolysis bio oil. Fourth Biomass Conference of the Americas, Oakland, California. September. 1999.

[17] Chiaramonti, D., Bonini, M., Fratini, E., Tondi, G., Gartner, K., Bridgwater, A. V., Grimm, H. P., Soldaini, I., Webster, A., Baglioni, P 2003: Development of Emulsions from Bio mass Pyrolysis Liquid and Diesel and Their Use in Engines - Part 1: Emulsion Production, Biomass \&Bioenergy, 25 pp. 85-99; Part 2: Tests in Diesel Engines, Bi mass \& Bioenergy, 25 pp. 101-111.

[18] Adegoke, I. A and Fuwape, J. A 2008: combustion properties of briquettes as affected by Production process. Proc. $1^{\text {st }}$ Annual Conf. in Forests and Forest Products, $16^{\text {th }} 19^{\text {th }}$ April 2008, FUTA. Nigeria. Pp 193-197.

[19] Russell, J. A., R. K. Miller and P. M. Molton, 1983. Formation of aromatic compounds from condensation reactions of cellulose degradation products. Biomass, 3: 43-57. DOI: 10.1016/0144- 4565 (83) 90007-0.

[20] Meier, D., O. Oasmaa and G. V. C. Peacocke. (1997). Properties of Fast Pyrolysis Liquids: Status of Test Methods. In A. V. Bridgwater and D. G. B. Boocock (Eds). Developments in Thermochemical Biomass Conversion. London: Blackie Academic \& Professional. 391-408.

[21] Bramer, E. A., Holthis, M. R., Brem, G. (2004). Development of a Cyclonic Reactor with Internal Particle Filter for the Flash Pyrolysis of Biomass; the Pyros Reactor, Proceedings, 2nd World Conference on Bioenergy, Rome, May 10-14, 2004, in press. 